The International Journal of Indian Psychology: Volume: 01 | Issue: 04 No. 2 | ISSN 2348-5396

\title{
The Effect of Vocational Training on Social Freedom and Adjustment of Rural Girls
}

\author{
Dr. Javnika Sheth*
}

\begin{abstract}
:
The main aim of the present research was to study and compare social freedom and adjustment among college girls belonging general and reserved category in rural areas. In this study my target sample was college girls. The reason for selecting college girls in rural area was to know their psychological attributes and analyzed it to discover important aspect of their personality and find out if the vocational training as extra- curricular activities, improve their social freedom and adjustment or not; that could be useful and meaningful for their future. To fulfill the motto of research, the Women social freedom scale -By L. I. Bhusan and Adjustment Inventory for college students- By A. K. P. Sinha and R. P. Singh was used. The random sampling technique was used in the selection of the sample for the present research. The sample further divided in to two groups. One is N1=60 girls from general category and N2=60 girls from reserved category (ST/SC/OBC). Thus, the total $\mathrm{N}=120$. Sample was taken from various college of Rural areas from Kheda district. The entire subject was in the age group of 16 to 25 years married or unmarried girls. They are from joint family or nuclear family. The pre-test and post-test method was applied. After pre test, I gave them vocational training (Beauty parlor) for three months as their income generation activities in future and then post test was given to all girls. The difference of the score of the pre-test and post-test was measured. The hypothesis was that vocational training will not increase their social freedom and adjustment. The result shows that there is the significant difference between their social freedom and adjustment after training. Their social freedom and adjustment level was increase after three months vocational training. The hypothesis was significant at .01 levels.
\end{abstract}

KEY WORDS: Vocational training, Social freedom, adjustment

*H.O.D in Psychology, Shah K S Arts and V M Parekh-Commerce College, Kapadwanj, Kheda, Gujarat, India 
The International Journal of Indian Psychology: Volume: 01 | Issue: 04 No. 2 | ISSN 2348-5396

\section{ADJUSTMENT:}

It deals with various changes the handle during college life. In addition to the physical changes students experience a great deal of emotional and developmental changes too. Astin,A.W.(1984). College is a huge transition for most of the students, especially for fresher's (first year students); it is a time for adjustment. An increasing amount of attention is being directed to the transition to higher education as experienced by traditional-age and adult students. It is a movement that incorporates a great deal of stress and challenge. Although some students are able to experience this transition as a challenge to personal growth, other students are overwhelmed by the changes and experience emotional maladjustment and depression.

Issues of adjustment and general development require persistent attention by campus professionals due to the immediate relevance to college success. Complex psychological histories often underpin these problems, further complicating treatment. These difficulties are often present as inefficiencies in coping with familial separation, time and stress management, basic study techniques, goal setting, relationship formation, handling emotions, and self-esteem crystallization. Personal, academic, social, and professional success depends on the student's ability to manage these aspects of their lives. Uehara,T.; Sakado, K.;Sakado,M.; Sato,T.; Someya,T (1999). Holmbek,G.N.\&Wandrei, M.L (1993) coated in their results that in this rapid changing world, adjustment is a persistent feature of human personality. A man of adjusting nature can lead a cheerful and wholesome life. The biological concept of adaptation has been borrowed and changed somewhat by the psychologist and renamed "adjustment" to emphasize the individual's struggle to get along or survive in his/her social and physical environment.

\section{FACTORS INFLUENCING THE ADOLESCENT'S ADJUSTMENT IS:}

Environment/Surroundings: Changes in the environment or surrounding require lot of adjustment. Learning to adjust to these changes improve one's ability and status within peer groups. Better adjustment of a person results in happy, cheerful \& wholesome life. Mathis,M.;Lecci,L.(1999).

Social Pressures: The stronger the drive for social acceptance, the more the child will try to develop personality traits that confirm to socially approved patterns of behavior.

Role Changes: Leadership role in the home, school, or neighborhood, helps to improve the child's adjustment level. 
The International Journal of Indian Psychology: Volume: 01 | Issue: 04 No. 2 | ISSN 2348-5396

School Achievement: One measures social achievement in terms of social acceptance and the holdings of leadership roles among children. The school achievement can be assessed depending upon the value, the school places on curricular or extracurricular activities. Thus, a child's performances influence his adjustment level accordingly.

Parental Favoritism: Parents who show favoritism toward their children encouraged them to develop feelings of self-importance. In a way, it helps in child's adjustment.

\section{TYPES OF ADJUSTMENT:}

Home Adjustment: Gauge and Bukoueski (1996) using a sample of 138 early adolescents and their parents examined the family and friendship with children's perceptions of adjustment and well being. The findings revealed that experiences of the family and friendship domains interact in their associations with children's impressions of their adjustment.

Health Adjustment: Baker and Siryk (1984) assessed the psychological adjustment of students in college. They recognized the importance of psychological adjustment, as well as the importance of academic and social integration into college systems.

Emotional Adjustment: Ezezek, (1994); and Holmbek \& Wandrei, (1993)shown in their results that those adolescents who are pattern satisfied with their life styles, whose urges and desires are met with satisfactions tends to enjoy life to the fullest and become emotionally adjusted. Some students adjust well to the college environment whereas others struggle with the transition, some leaving school entirely.

Social Adjustment: Adolescence is a period of social expansion and development. Guo (1998) found that females scored higher than males on reading recognition and comprehension tests after controlling family background factors.

Educational Adjustment: Broh, B.A. (2002) Linking extracurricular programming to academic achievement and say that School and college are the world where friendships are made and those who do not easily make friends feel isolated. Particularly, minority and economically less favored groups may feel lack of status and acceptance. A well-adjusted adolescent meets his/her college environment with the initiative of full sharing with others and for the optimum development of himself/ herself. Student's perceptions of their teachers' interest in their education also seem to have implications for their expected and aspired educational attainment. Belch,H.A .;Gebel,M.and Mass,G.M.(2001)
(C) 2014 www.ijip.in
July-September 2014
46 | P a g e 
The International Journal of Indian Psychology: Volume: 01 | Issue: 04 No. 2 | ISSN 2348-5396

\section{EXTRA-CURRICULAR ACTIVITIES IMPROVE LIFE- ADJUSTMENT:}

Some research findings suggest that there is a positive relationship between student's participation in extracurricular activities and their adjustment in home, college and at work. Students who participate in such activities appear to be superior in most respects to those who do not. When students, teachers, parents and alumni are asked their opinions regarding the value of participation in extracurricular activities, their attitude is generally quite favorable. Large numbers say that such participation gives training for work and other out of school experiences, keep students in school longer, develops making friendships and assists in adjustment in home, college and at work.

\section{ACTIVITIES BUILD SELF ESTEEM:}

What Self-Esteem Is: Self-esteem includes the ideas of confidence in yourself and respect for yourself. Having good self-esteem involves having a positive idea of your own self-worth, liking who you are and feeling aware of your own positive and negative qualities.

Skill Development: Extracurricular involvement can provide young girls with new skills. The ability is making new creation, perform a new activity or learn more about something they love, can make them feels better about themselves. It can also give them a better sense of who they are and help them to develop a stronger personality. After-college activities can also teach young people Vocational activities to improve their skill development and for income generation in future.

Life Skills: Within the framework of extracurricular activities, girls learn self-esteem related skills that will serve them long after their college days have ended. Enroll girls in Creativity or other activities and watch them develop the ability to interact with new people in an easy and positive way and to compete in a healthy way.

Creativity: After-college activities can provide an outlet for creativity and problem-solving. Obvious choices are arts and crafts, music, performing arts, and other activities can also teach problem-solving skills. The best activities for college girls are those that encourage their natural curiosity and interests. 
The International Journal of Indian Psychology: Volume: 01 | Issue: 04 No. 2 | ISSN 2348-5396

Teamwork and Respect: Teamwork is an important life skill both in home life and at work. Various group activities require children to work together to achieve a common goal and remove the focus from the individual to the team. Respect for coaches, teachers, leaders and their peers can also be developed through group activities.

Time Management: Participating in one or more activities can teach a student how to prepare for income generation, family life, and their after-college activities as well and learn the importance of priorities and planning.

Self-Confidence: For a teen who is not gifted academically, the chance to excel in the arts or in extracurricular activities, for example, can make a huge difference in self-esteem. Additionally, when children learn new skills and engage in social activities, they become more self-confident. Learning social skills, like cooperation, negotiation, and conflict resolution, in a fun and relaxed environment will help them interact appropriately with others - a skill valuable in all aspects of life from home life to the workplace.

Stress Relief: Many activities take place in a relaxing environment and begin with warm-up techniques or exercises. These promote healthy methods for dealing with stress. In an increasingly complex and pressure-oriented world, the more we are able to find positive ways to deal with stress, the better we are. All enjoyable activities provide a source of stress relief.

Real-World Skills: Many extracurricular activities - such as beautification, jewelary making, greetings card making, etc. - teach real-world skills, which can lead to lifelong interests, even careers for girls in this era. Activities can teach real world skills that encourage life-long interests. They help the person explore their physical, creative, and social potential. They allow the person to find out where their career or political interests may lie.

\section{METHOD:}

\section{OBJECTIVES:}

The main objectives of the present research are as under:

1. Measure the level of social freedom among college girls belonging general and reserved category in rural area.

2. Measure the level of adjustment among college girls belonging general and reserved category in rural area.

3. To compare the effect of training between general and reserved category girls. 
The International Journal of Indian Psychology: Volume: 01 | Issue: 04 No. 2 | ISSN 2348-5396

\section{HYPOTHESIS:}

For the present study the following major hypothesis are formulated.

1. There will be no significant difference between social freedom and adjustment.

2. The vocational training will not increase the social freedom and adjustment of girls.

\section{TOOL AND PROCEDURE:}

1 Women social freedom scale -By L.I.Bhusan

2. Adjustment Inventory for college students- By A.K.P.Sinha and R.P.Singh

\begin{tabular}{|l|l|l|}
\hline N1 & N2 & total \\
\hline $\begin{array}{l}\text { 60girls (general } \\
\text { category) }\end{array}$ & $\begin{array}{l}60 \text { girls (reserved } \\
\text { category- } \\
\text { ST/SC/OBC) }\end{array}$ & $\begin{array}{l}\text { 120 GIRLS from } \\
\text { college } \\
\text { Age group=16 to } \\
25 \text { married or } \\
\text { unmarried college } \\
\text { students from } \\
\text { Kheda district- } \\
\text { Rural area }\end{array}$ \\
\hline
\end{tabular}

The random sampling technique was used in the selection of the sample for the present research. The sample further divided in to two groups. One is $\mathrm{N} 1=60$ girls from general category and $\mathrm{N} 2=60$ girls from reserved category $(\mathrm{ST} / \mathrm{SC} / \mathrm{OBC})$. Thus, the total $\mathrm{N}=\underline{\mathbf{1 2 0}}$. Sample was taken from various college of Rural areas from Kheda district. The entire subject was in the age group of 16 to 25 years married or unmarried girls. Their monthly income is about 10,000 to 20,000 Rs per month.

\section{RESULTS:}

TABLE: 1 Pre test and Post test score statistics of reserved category girls

\begin{tabular}{|l|l|l|l|l|}
\hline PAIR: 1 & Mean & N & Std. Deviation & Std. Error Mean \\
\hline Pre-test Score & 17.28 & 60 & 1.585 & .205 \\
\hline Post-test Score & 19.77 & 60 & 1.294 & .167 \\
\hline
\end{tabular}


The International Journal of Indian Psychology: Volume: 01 | Issue: 04 No. 2 | ISSN 2348-5396

TABLE: 2 Effect of Vocational Training on reserved category girls- level of significant

\begin{tabular}{|l|l|l|c|}
\hline Pair: 1 & N & Co-relation & Level of significant \\
\hline $\begin{array}{l}\text { Pre-test and Post-test } \\
\text { score }\end{array}$ & 60 & .413 & $\mathbf{. 0 1}$ \\
\hline
\end{tabular}

TABLE: 3 Pre test and Post test score statistics of general category girls

\begin{tabular}{|l|l|l|l|l|}
\hline PAIR: 1 & Mean & N & Std. Deviation & Std. Error Mean \\
\hline Pre-test Score & 20.13 & 60 & 1.362 & .241 \\
\hline Post-test Score & 17.41 & 60 & 1.811 & .320 \\
\hline
\end{tabular}

TABLE: 4 Effect of Vocational Training on general category girls- level of significant

\begin{tabular}{|l|l|l|c|}
\hline Pair: 1 & $\mathrm{~N}$ & Co-relation & Level of significant \\
\hline $\begin{array}{l}\text { Pre-test and Post-test } \\
\text { score }\end{array}$ & 60 & .293 & $\mathbf{. 0 1}$ \\
\hline
\end{tabular}

TABLE: 5 Pair differences

\begin{tabular}{|c|c|c|c|c|c|c|c|c|}
\hline & & \multicolumn{4}{|c|}{ Pair differences } & \multirow[t]{2}{*}{$\mathrm{t}$} & \multirow{2}{*}{$\begin{array}{l}\text { df } \\
\text { Ouph }\end{array}$} & \multirow{2}{*}{$\begin{array}{l}\text { Level of } \\
\text { significant }\end{array}$} \\
\hline & Mean & SD & \begin{tabular}{|l} 
SD \\
Error \\
Mean
\end{tabular} & $\begin{array}{l}95 \% \\
\text { Interva } \\
\text { differe }\end{array}$ & $\begin{array}{l}\text { onfidence } \\
\text { of the }\end{array}$ & & & \\
\hline \multirow{2}{*}{$\begin{array}{l}\text { Score } \\
\text { of } 120 \\
\text { samples }\end{array}$} & \multirow{2}{*}{2.719} & \multirow[b]{2}{*}{1.922} & \multirow[b]{2}{*}{.340} & Lower & upper & \multirow[b]{2}{*}{8.004} & \multirow[b]{2}{*}{119} & \multirow[b]{2}{*}{.01} \\
\hline & & & & 2.026 & 3.412 & & & \\
\hline
\end{tabular}

1) TABLE: 1 show the Pre test and Post test score statistics of reserved category girls. Their Mean of pre-test is 17.28 and mean of post-test is 19.77 .

2) TABLE: 2 show the Effect of Vocational Training on reserved category girls. The results are significant at .01 levels.

3) TABLE: 3 show the Pre test and Post test score statistics of general category girls. Their Mean of pre-test is 20.13 and mean of post-test is 17.41 .

4) TABLE: 4 show the Effect of Vocational Training on general category girls. The results are significant at .01 levels.

5) TABLE: 5 show the Pair differences and overall result of the girls. The results are significant at .01 levels. 
The International Journal of Indian Psychology: Volume: 01 | Issue: 04 No. 2 | ISSN 2348-5396

\section{DISCUSSION:}

The results show the significant difference between the girls of general and reserved category regarding their social freedom and adjustment. The results also show the significant difference between the pre test score and post test score. It means the vocational training has increased the score of social freedom of girls. The causes behind less social freedom are their age, atmosphere, responsibilities, self awareness, maturity, attitudes and so on. In Indian society, the role of boys and girls are very different for study, daily routine work, games, dress style, timing for roaming outside the house and many other that create less social freedom of the girls. If we provide the skill development training for them, they can earn money, and became more confident. By this way we can increase the social freedom of girls. Finally, the girls having more social freedom try to solve the problems in their life. They respond their problems in their daily life and try to solve by themselves.

\section{CONCLUSION:}

The present study no doubt with its better control and methodology supports the theory about the social freedom of the subjects over other types of girls from general and reserved category in rural area, the results show the significant differences between pre-test and post-test scores. In future, it would be more interesting study if we take rural and tribal girls, the another skill development program for girls, the comparison between married and unmarried girls and so on. Anyway, there being comparatively fewer studies in our Indian context and culture in area of newer approach to social freedom and adjustment, further research needs to be pursued in context of our culture with more careful methodology to compare the results of the western culture with those in our eastern culture.

\section{REFERENCE:}

1. Astin,A.W.(1984).Student involvement:A development theory for higher education. Journal of college student P e r s o n n e 1,22,297 - 308 .

2. Baker, R.W. and Siryk, B. (1984). Measuring adjustment to college. Journal of Counseling Psychology, 31, 179-189. 
The International Journal of Indian Psychology: Volume: 01 | Issue: 04 No. 2 | ISSN 2348-5396

3. Belch,H.A .;Gebel,M.and Mass,G.M.(2001).Relationship between studen t recreation complex use, academic performance, and persistence of first time freshman.NASPA journal,38(2),254-268.

4. Ezezek ,K.(1994) College getting in and staying in .Journal of College Admission, 142, 2-3.

5. Gauge,C. ; Bukowsti ,W.M.(1996). Interaction between family environment and friendship and association with self perceived wellbeing during adolescent. Journal of child development, vol.67 (5), 2201-2216.

6. Gerdes,H., and Mallinckrodt,B.(1994).Emotional, Social, and academic adjustment of college student : a longitudinal study of retention. Journal of Counseling and Development, 72 ( \# 3 ), 1 - 14 .

7. Guo,R.(1998).Social Adjustment of males and females ,Psychological Review, 82,7276.

8. Holmbek ,G.N.\& Wandrei, M.L.(1993) . Individual and relational predictors of adjustment in first year college students. Journal of Counseling Psychology, 40, 73-78.

9. Mathis,M.;Lecci,L.(1999).Hardiness and College Adjustment: Identifying students in need of services. Journal of College Student Development, Vol.40 (3) 305-309pp.

10. Uehara, T.; Sakado, K.; Sakado, M.; Sato, T.; Someya, T. (1999) the effect of skill development training on girls. Journal of social development, vol.6 (3), 01-16. 